\title{
Alpha Liquid-Scintillation Spectrometry used for the Measurement of Uranium/Thorium-Disequilibria in Soil Samples*
}

\author{
By B. Füeg, T. Tschachtli and U. Krähenbühl \\ Departement für Chemie und Biochemie, Labor für Radio- und Umweltchemie, Universität Bern, 3012 Bern, Switzerland
}

(Received February 20, 1997; accepted in revised form May 20, 1997)

\author{
Alpha liquid-scintillation / \\ Extraction chromatographic resin / \\ Uranium/Thorium-disequilibrium / \\ Soil / Environmental sample
}

\begin{abstract}
Summary
For the measurements of low-level radioactivity of natural samples, it is of interest to have a system with high counting efficiency. Alpha liquid-scintillation spectrometry is attractive, because it offers a $4 \pi$ geometry. Some chemical separation can be obtained using extractive scintillators. Due to quenching problems for natural samples, additional separation power is needed. A new sample preparation method was developed employing extraction chromatographic resin for measuring ${ }^{238} \mathrm{U}$, ${ }^{234} \mathrm{U},{ }^{232} \mathrm{Th},{ }^{230} \mathrm{Th},{ }^{228} \mathrm{Th}$ and ${ }^{226} \mathrm{Ra}$ in soil samples, without using any uranium- or thorium-tracer for determining the chemical yields. This method was tested by analyzing the two different reference materials, IAEA-375, soil from Tschernobyl, as well as IAEA SDA-1, a deep-sea sediment with a high calcium content. For all analyzed radionuclides the recoveries were better than $90 \%$ with errors (confidence level of 95\%) smaller than 5\%. The minimal detectable concentration ranges between 0.2 and $0.8 \mathrm{~Bq} / \mathrm{kg}$, based on a one gram aliquot of sample and 80 '000 seconds counting time.
\end{abstract}

\section{Introduction}

The goal of the present work is the development of a method, which allows measuring the uranium/thoriumdisequilibria as well as ${ }^{226} \mathrm{Ra}$-activity in soils of karst formations [1] by alpha liquid-scintillation spectrometry.

Extensive research was performed for counting $\alpha$ emitters by liquid-scintillation, and to make this method applicable to environmental assays [2-6]. However, attractive as this idea is because of near $100 \%$ counting efficiency and no self-absorption, there are several problems such as poor energy resolution, high $\beta$ - and $\gamma$-background as well as the transfer of the nuclides of interest into the scintillator, that often prevent a successful application of liquid-scintillation. A new technique was developed combining solvent extraction and alpha liquid-scintillation $[7,8]$. On the other side pulse-shape discrimination was introduced [9], which allows the separation of alpha-particle-pro-

\footnotetext{
* Presented at the 4th International Conference on Nuclear and Radiochemistry, St. Malo, France, September 1996.
}

duced pulses from beta- and gamma-produced pulses. High backgrounds, as they are typical for liquid-scintillation counting (LSC), may now be reduced. For the PERALS $^{\circledast}$-system (acronym for Photon/Electron-Rejecting Alpha Liquid-Scintillation) for instance, background blanks are less than $0.01 \mathrm{cpm}$ under a region corresponding to alpha-energies from 4 to $7 \mathrm{MeV}$ [10]. Finally improvements in detector designs were investigated in order to obtain better energy resolutions [11].

Different authors have demonstrated, that solvent extraction in combination with liquid-scintillation spectrometry and pulse-shape discrimination is a rapid and accurate method for the low-level assay of alphaemitters without using any uranium- or thorium-tracer for determining the yields [12-15]. Therefore, this method is attractive for a wide range of environmental alpha-assay [16-20].

However, certain limitations remain when using the PERALS ${ }^{\infty}$-system for detecting alpha-radiation. The typical energy-resolution obtained with surface barrier detectors are around $20 \mathrm{keV}$ FWHM [21], and is therefore 10 to 15 times superior to those achieved with a PERALS ${ }^{\circledR}$-system $(200-300 \mathrm{keV}$, FWHM [22]). Often, such a alpha energy-resolution results, due to the application of selective extractive scintillators. Spectra collected on a multichannel analyzer allow nuclide identification and concentration determination. In some cases, for instance because of daugther-ingrowth, additional calculations are necessary.

A second problem that may occur by measuring alpha-emitters with the PERALS ${ }^{\circledR}$-system are quenching effects [23]. There are two different quenching processes causing losses in both pulse-shape and energy resolution. Chemical quenchers, non-light producing molecules, dissipate their energy in molecular, vibrational and rotational modes, and thus produce heat rather than light, when they return to their ground state. Compounds which cause heavy quenching are water, oxygen, heavy elements, most chlorine-containing compounds, nitrate, alcohols and ketones, whereas sulfate and perchlorate do not quench by any significant amount. A second quenching process is caused by colored materials, if present in the solution, they may absorb the light of the scintillation process before it can reach the phototube. Color quenchers include colored organic compounds, humic acids and colored metal ions. 
Table 1. The ingredients of the extractive scintillators.

\begin{tabular}{|c|c|c|c|}
\hline \multirow[t]{2}{*}{ Ingredient } & \multicolumn{3}{|c|}{ Extractive scintillators } \\
\hline & $\mathrm{URAEX}_{a}^{\mathrm{TM}}$ & THOREX ${ }_{a}^{\mathrm{T}}$ & $\mathrm{RADEX}_{\alpha}^{\mathrm{Tm}}$ \\
\hline Scintillator & $\begin{array}{l}\text { 2-(4'-biphenylyl)-6-phenyl- } \\
\text { benzoxazole (PBBO) }\end{array}$ & $\begin{array}{l}\text { 2-(4'-biphenylyl)-6-phenyl- } \\
\text { benzoxazole (PBBO) }\end{array}$ & $\begin{array}{l}\text { 2-(4'-biphenylyl)-6-phenyl- } \\
\text { benzoxazole (PBBO) }\end{array}$ \\
\hline Extractant & tertiary amine $(\mathrm{MG}>300)$ & primary amine $(\mathrm{MG}>300)$ & $\begin{array}{c}\text { neo-carboxylic acid }(270<\text { MG }>350) \\
\text { and dicyclohexano- } 21 \text {-crown- } 7^{\mathrm{a}}\end{array}$ \\
\hline Energy transfer agent & naphthalene & naphthalene & naphthalene \\
\hline Solvent & toluene & toluene & toluene \\
\hline
\end{tabular}

a mole ratio neo-carboxylic acid: crown ether $=2: 1$

In order to produce best time and energy resolution these quenching effects must be minimized. This can be achieved by separation and by preconcentration of the interesting radionuclides. A novel extraction chromatographic resin comprised of diamyl amylphosphonate sorbed on Amberlite ${ }^{\mathrm{TM}}$ as well as the application for groundwater and soil samples has been described [24].

\section{Experimental}

\subsection{Reagents}

All chemicals were analytical grade and used without further purification. The extractive scintillators were purchased from EG\&G ORTEC. The compositions of URAEX $_{\alpha}^{\mathrm{TM}}, \mathrm{THOREX}_{\alpha}^{\mathrm{TM}}$ and RADEX $\mathrm{T}_{\alpha}^{\mathrm{T}}$ are given in Table 1. For preconcentration and separation of the uranium and thorium U/TEVA - Spec resin, commercially available from EICHroM Industries Inc., is used. This resin is produced by sorbing diamyl amylphosphonate on an inert polymeric support (Amberlite XAD-7); the particle diameters varies between 100 and $150 \mu \mathrm{m}$ [23]. The ${ }^{225} \mathrm{Ra}$-tracer solution is obtained by eluting ${ }^{225} \mathrm{Ra}$ with $3 \mathrm{M} \mathrm{HNO}$ from ${ }^{229} \mathrm{Th}$ sorbed on U/TEVA - Spec resin twice per month. The two different reference materials IAEA-375 and SDA-1 were both purchased from the International Atomic Energy Agency (IAEA), Vienna. The certified ${ }^{226} \mathrm{Ra}$-standard solution was purchased from the Radiochemical Centre, Amersham.

\subsection{Sample preparation}

Approximately one gramme of the soil sample is placed in a Teflon-lined high pressure vessel. Two $\mathrm{mg}$ of $\mathrm{Ba}$ is added as $\mathrm{Ba}\left(\mathrm{NO}_{3}\right)_{2}$. The solid samples were dissolved using mineral-acids and heated by microwave excitation. The dissolution of the sample is done in two steps:

- In the first step $6 \mathrm{ml}$ of conc. $\mathrm{HNO}_{3}(65 \%)$ and $1.5 \mathrm{ml}$ of conc. $\mathrm{HClO}_{4}(70 \%)$ are added.

- In a second step, the residue (silicates) is treated with $3 \mathrm{ml} \mathrm{HF}$ and $1 \mathrm{ml} \mathrm{HNO}_{3}$. The $\mathrm{HF} / \mathrm{HNO}_{3}-$ solution is evaporated to dryness. The cake is dissolved in $2 \mathrm{ml}$ of conc. $\mathrm{HNO}_{3}(65 \%)$ and evaporated a

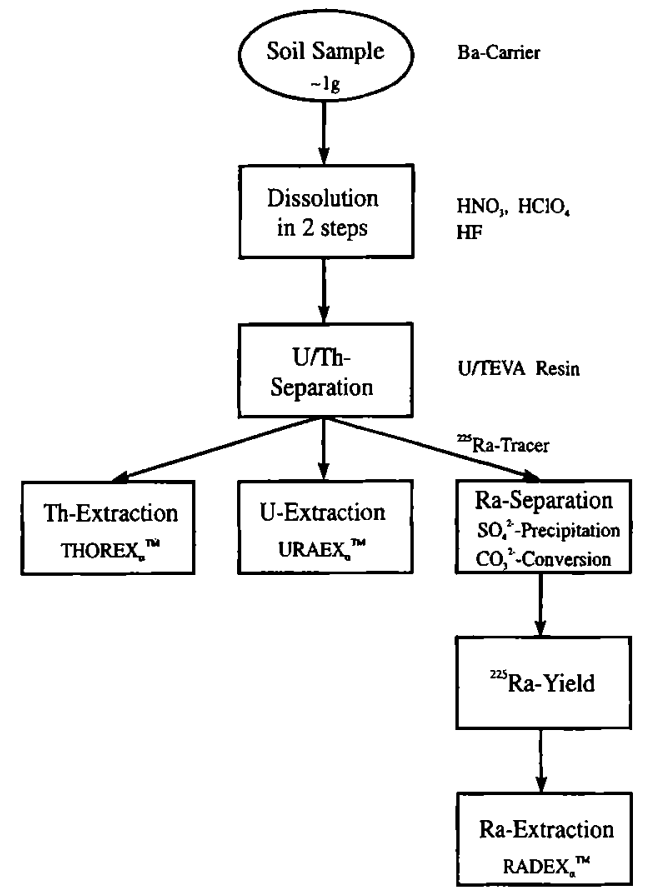

Fig. 1. Simplified flow-chart of the chemical separations used for measurements of uranium, thorium and radium in soil samples.

second time to dryness to remove traces of HF. The residue is then dissolved in $1 \mathrm{ml}$ of conc. $\mathrm{HNO}_{3}$.

The resulting solutions are combined and converted to the nitrate system $\left(3 \mathrm{M} \mathrm{HNO}_{3}\right.$ and $0.5 \mathrm{M}$ $\left.\mathrm{Al}\left(\mathrm{NO}_{3}\right)_{3}\right)$. The presence of $\mathrm{HClO}_{4}$ does not disturb the following separation steps. Fig. 1 shows a simplified flow-chart of the chemical separations used for measurements of uranium, thorium and radium in soil samples.

\subsection{Uranium and thorium separation and extraction chemistry $[20,24,25]$}

For the separation of uranium and thorium, the prepared sample solution is loaded onto a column (bed volume $=2.0 \mathrm{ml}$; bed height $=4.0 \mathrm{~cm})$ containing an extraction chromatographic resin (U/TEVA - Spec). Five $\mathrm{ml} 9 \mathrm{M} \mathrm{HCl}$ are passed, to convert the resin to the chloride system. First, thorium is eluted with $15 \mathrm{ml}$ $5 \mathrm{M} \mathrm{HCl}$ followed by uranium with $20 \mathrm{ml} 0.02 \mathrm{M} \mathrm{HCl}$. 
One $\mathrm{ml}$ of conc. nitric acid is added to destroy any extractant that may have been stripped from the column and may interfere with the counting technique. The solutions are then evaporated to dryness. It is important that no traces of $\mathrm{HCl}$ and $\mathrm{HNO}_{3}$ remain, as both mineral acids are very strong quenchers and if present in the final cocktail diminish time and energy resolution. The residue is dissolved in $6 \mathrm{ml} 0.1 \mathrm{M}$ sulfuric acid and $1.8 \mathrm{~g}$ of sodium sulfate are added, to convert both solutions to a sulfate system at $\mathrm{pH} 0$ to 1. The extraction into a scintillator containing a highmolecular-weight primary amine (THOREX ${ }_{\alpha}^{\mathrm{TM}}$ ) will remove thorium, as the extraction into a scintillator containing a high-molecular-weight tertiary amine $\left(\mathrm{URAEX}_{\alpha}^{\mathrm{m}}\right.$ ) will remove uranium quantitatively.

\subsection{Radium separation and extraction chemistry $[26,27]$}

Radium and barium are not retained by U/TEVA . Spec resin. After passing the column, an accuratelyknown quantity of ${ }^{225} \mathrm{Ra}$-tracer $(\sim 5 \mathrm{~Bq})$ is added. The sample was spiked after passing the resin, because traces of ${ }^{229} \mathrm{Th}$ present in the ${ }^{225} \mathrm{Ra}$ solution may disturb the thorium measurements. Radium is then coprecipitated with barium sulfate by adding $3 \mathrm{ml} 6 \mathrm{M}$ $\mathrm{H}_{2} \mathrm{SO}_{4}$. The precipitate is converted to the corresponding carbonate by heating with $10 \mathrm{ml}$ of a saturated potassium carbonate solution for $90 \mathrm{~min}$. After washing the carbonates with $5 \mathrm{ml} 0.1 \mathrm{M} \mathrm{K}_{2} \mathrm{CO}_{3}$ and twice with 3 to $5 \mathrm{ml}$ of distilled water, they are dissolved in $0.5 \mathrm{M}$ $\mathrm{HNO}_{3}$ and $\mathrm{CO}_{2}$ is expelled. All solids should dissolve. Any persisting solids will be sulfates. In this case the conversion steps have to be repeated. Particular samples with a high calcium content sometimes may require a rerun. The liquid is then evaporated to dryness to remove excess nitric acid. The resulting solids are dissolved in $2 \mathrm{ml}$ of distilled water. The total losses in the chemical separation steps can be corrected by counting the $40.0 \mathrm{keV} \gamma$-line of ${ }^{225} \mathrm{Ra}$. The $\mathrm{pH}$ of this solution is adjusted to be greater than 10 by adding $1 \mathrm{ml}$ of $0.3 \mathrm{M} \mathrm{NaOH}$ and $1 \mathrm{ml}$ of $0.3 \mathrm{M} \mathrm{NaNO}_{3}$ to improve best extraction conditions. Radium is then selectively extracted into an extractive scintillator, containing a synergistic reagent mixture of a high-molecular-weight-branched carboxylic acid and a crownether (RADEX $\left.{ }_{\alpha}^{\mathrm{m}}\right)$.

\subsection{Instrumentation}

PERALS $^{\Phi}$-spectrometers $\left.{ }^{1}\right)$ including pulse shape discrimination (PSD), previously developed at ORDELA, were used to count the alpha radiation of the radionuclides ${ }^{238} \mathrm{U},{ }^{234} \mathrm{U},{ }^{232} \mathrm{Th},{ }^{230} \mathrm{Th},{ }^{228} \mathrm{Th}$ and ${ }^{226} \mathrm{Ra}$.

The $40.0 \mathrm{keV}$-line of the ${ }^{225} \mathrm{Ra}$-tracer was measured with a High-Purity Germanium Coaxial Well Photon Detector System (EG\&G ORTEC).

\footnotetext{
Manufactured by Oak Ridge Detector Laboratory (ORDELA), Oak Ridge, Tennessee.
}
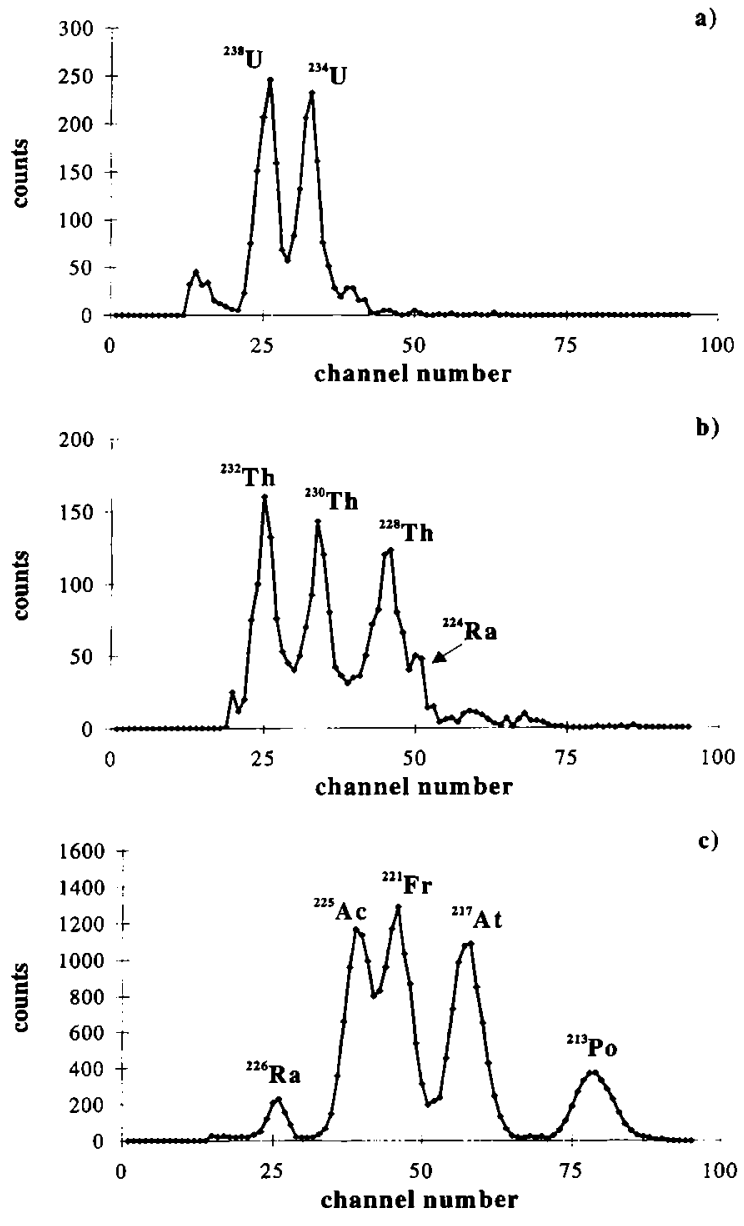

d)

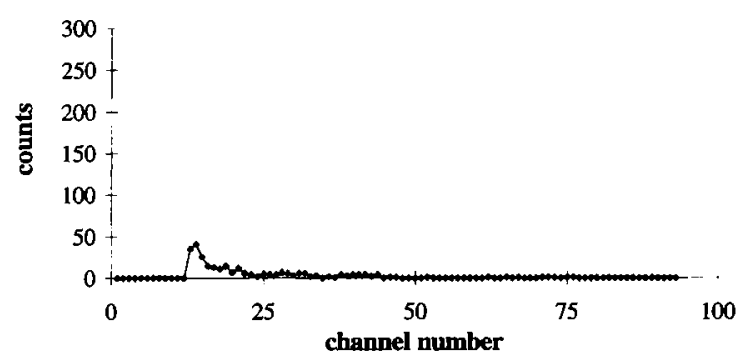

Fig. 2. Typical PERALS ${ }^{\circledast}$ spectra for the determination of uranium, thorium and radium: a) $U$ in reference soil IAEA-375, b) Th in reference soil IAEA-375, c) Ra in deep sea sediment IAEA SDA-1, using ${ }^{225} \mathrm{Ra}$ as yield monitor, d) background measurement

\subsection{Counting}

The samples are sparged with toluene-saturated argon for 3 to 5 minutes to minimize oxygen quenching and to improve energy resolution and pulse-shape discrimination before counting in a PERALS ${ }^{\otimes}$ detector.

\section{Results and discussion}

Dissolving the soil sample in one step with a mixture of nitric-, perchloric- and hydrofluoricacid, about 60 to $80 \%$ of the added ${ }^{225}$ Ra-activity was found in an almost insoluble precipitate. Therefore, a dissolution 
Table 2. Detection limits for the investigated radionuclides.

\begin{tabular}{cc}
\hline${ }^{238} \mathrm{U}$ & 0.2 \\
${ }^{234} \mathrm{U}$ & 0.2 \\
${ }^{232} \mathrm{Th}$ & 0.2 \\
${ }^{230} \mathrm{Th}$ & 0.2 \\
${ }^{228} \mathrm{Th}$ & 0.2 \\
${ }^{226} \mathrm{Ra}$ & $0.4^{\mathrm{a}}-0.8^{\mathrm{b}}$ \\
\hline
\end{tabular}

"Calculated for a ${ }^{225}$ Ra-recovery of $70 \%$.

b Calculated for a ${ }^{225}$ Ra-recovery of $35 \%$.

in two steps had to be introduced to avoid any fluoride precipitation.

Typical spectra of uranium, thorium, radium, collected immediately after the samples were prepared and of background measurement are shown in Fig. 2. The samples were measured for 80 '000 seconds in order to collect at least 500 counts. An alpha energy resolution between $200 \mathrm{keV}$ and $400 \mathrm{keV}$ FWHM is obtained, so that an identification of almost all interesting nuclides is possible. Only for ${ }^{228} \mathrm{Th}$ with an $\alpha$-particle energy of $5.42 \mathrm{MeV}$ and the ingrowth of its daughter ${ }^{224} \mathrm{Ra}$ with an $\alpha$-particle energy of $5.69 \mathrm{MeV}$ the resolution is not high enough, and therefore an ingrowth correction factor has to be calculated (1.0834, when starting the measurements immediately after extraction and counting for $80^{\prime} 000$ seconds). $\mathrm{HCl}$ and $\mathrm{HNO}_{3}$ are very strong quenchers. They diminish time and energy resolution, if present in the final cocktail. Therefore it is very important that any traces of both mineral acids are removed before carrying out the extraction steps.

The detection limits for all investigated radionuclides are shown in Table 2 . They are determined for one gram of soil sample and a counting time of 80 '000 seconds. For the uranium- and the thoriumisotopes the detection limits are around $0.2 \mathrm{~Bq} / \mathrm{kg}$, whereas for ${ }^{226} \mathrm{Ra}$ the value is two to four times higher. This difference for ${ }^{226} \mathrm{Ra}$ is mainly due to losses in the separation steps. A ${ }^{225}$ Ra-recovery of $70 \%$, typical for calcium poor samples, leads to a detection limit of $0.4 \mathrm{~Bq} / \mathrm{kg}$, whereas a ${ }^{225} \mathrm{Ra}$-recovery of $35 \%$, typical for calcium rich samples, increases it by a factor two.
Table 4. Differences in behavior of ${ }^{133} \mathrm{Ba}$ - and ${ }^{225} \mathrm{Ra}$-tracers during the separation steps. Errors are $\pm 2 \sigma$ counting errors.

\begin{tabular}{lccc}
\hline Sample & $\begin{array}{c}{ }^{133} \mathrm{Ba}- \\
\text { recovery } \\
{[\%]}\end{array}$ & $\begin{array}{c}{ }^{225} \mathrm{Ra}- \\
\text { recovery } \\
{[\%]}\end{array}$ & $\begin{array}{c}{ }^{226} \mathrm{Ra}- \\
\text { recovery } \\
{[\%]}\end{array}$ \\
\hline $\begin{array}{l}\text { Water, spiked with }{ }^{226} \mathrm{Ra} \\
\quad(10 \mathrm{~Bq})\end{array}$ & $88.7 \pm 4.9$ & $80.1 \pm 4.0$ & $81.0 \pm 1.0$ \\
$\begin{array}{l}\text { Soil sample (IAEA-375) } \\
\begin{array}{l}\text { Sediment sample } \\
\text { (IAEA SDA-1) }\end{array}\end{array}$ & $79.4 \pm 5.1$ & $68.7 \pm 4.1$ & $68.0 \pm 5.2$ \\
$\begin{array}{l}\text { 226 } \mathrm{Ra}-\text { standard solution } \\
\text { (direct extraction) }\end{array}$ & $52.3 \pm 6.0$ & $40.4 \pm 5.2$ & $39.0 \pm 4.8$ \\
\hline
\end{tabular}

The method described above was tested by analyzing the following solid reference materials: IAEA-375 (soil) and IAEA SDA-1 (deep-sea sediment). The results are listed in Table 3. Recoveries higher than $90 \%$ with errors (at a confidence level of $95 \%$ ) smaller than $5 \%$ result for all measured radionuclides. The analytical data, as displayed in the table, indicate the accuracy of the procedure when performed on various activities of uranium, thorium and radium in the reference materials. No significant differences in the recoveries between the isotopes of uranium and thorium, respectively, can be observed. Only for ${ }^{232} \mathrm{Th}$ the yield is lower than for ${ }^{230} \mathrm{Th}$ and ${ }^{228} \mathrm{Th}$ because of quenching processes, which affect the measurements more at lower than at higher energies.

In contrary to uranium and thorium, where the composition of the soil seems to have no effect on the separation chemistry, the chemical yield of the radium separation depends on the content of calcium. High calcium concentration causes great losses (up to $70 \%$ ) of radium and barium in the precipitation and conversion steps. Increasing the amount of the Ba-carrier improves the ${ }^{225}$ Ra-tracer recovery, but disturbs on the other side the extraction of ${ }^{226} \mathrm{Ra}$ by RADEX $\mathrm{R}_{\alpha}^{\mathrm{Tm}}$. While $1 \mathrm{mg}$ of barium present in the sample will lead to a quantitative extraction, $10 \mathrm{mg}$ reduce the yield of the extraction of ${ }^{226} \mathrm{Ra}$ to less than $75 \%$. In earlier experiments, instead of ${ }^{225} \mathrm{Ra},{ }^{133} \mathrm{Ba}$ was tested as tracer for recovery-determinations as proposed by McDowell

Table 3. Comparison of measured and expected activities for reference materials. The errors are at a condifence level of $95 \%$.

\begin{tabular}{|c|c|c|c|c|c|c|c|c|}
\hline \multirow[t]{2}{*}{ Nuclide } & \multicolumn{4}{|c|}{ IAEA-375 $(\mathrm{N}=10)$} & \multicolumn{4}{|c|}{ IAEA SDA-1 $(\mathrm{N}=10)$} \\
\hline & $\begin{array}{c}\text { reference } \\
{[\mathrm{Bq} / \mathrm{kg}]}\end{array}$ & $\begin{array}{c}\text { confidence } \\
\text { interval } \\
(95 \%) \\
{[\mathrm{Bq} / \mathrm{kg}]}\end{array}$ & $\begin{array}{c}\text { measured } \\
{[\mathrm{Bq} / \mathrm{kg}]}\end{array}$ & $\begin{array}{c}\text { recovery } \\
{[\%]}\end{array}$ & $\begin{array}{c}\text { reference } \\
{[\mathrm{Bq} / \mathrm{kg}]}\end{array}$ & $\begin{array}{c}\text { confidence } \\
\text { interval } \\
(95 \%) \\
{[\mathrm{Bq} / \mathrm{kg}]}\end{array}$ & $\begin{array}{c}\text { measured } \\
{[\mathrm{Bq} / \mathrm{kg}]}\end{array}$ & $\begin{array}{c}\text { recovery } \\
{[\%]}\end{array}$ \\
\hline${ }^{238} \mathrm{U}$ & 22.6 & $20.6-24.6$ & $20.8 \pm 0.6$ & $92.1 \pm 2.4$ & 7.3 & $6.3-9.5$ & $6.62 \pm 0.27$ & $90.6 \pm 3.7$ \\
\hline${ }^{2.34} \mathrm{U}$ & $25.0^{\mathrm{a}}$ & $17.0-32.0$ & $22.8 \pm 0.8$ & $91.2 \pm 3.0$ & 7.3 & $7.0-\quad 7.7$ & $6.69 \pm 0.26$ & $91.7 \pm 3.6$ \\
\hline${ }^{2.32} \mathrm{Th}$ & 20.7 & $20.1-21.3$ & $19.0 \pm 0.7$ & $91.6 \pm 3.4$ & 12.2 & $10.5-13.8$ & $11.4 \pm 0.3$ & $93.3 \pm 2.7$ \\
\hline${ }^{230} \mathrm{Th}$ & $-\mathrm{b}$ & - & $14.6 \pm 0.9$ & - & 101.4 & $92.0-106.0$ & $99.1 \pm 2.6$ & $97.7 \pm 2.5$ \\
\hline${ }^{228} \mathrm{Th}$ & $21.0^{\mathrm{a}}$ & $17.0-25.0$ & $19.5 \pm 0.8$ & $92.7 \pm 3.7$ & 12.3 & $10.2-12.9$ & $11.9 \pm 0.3$ & $96.7 \pm 2.5$ \\
\hline${ }^{226} \mathrm{Ra}$ & 20.0 & $18.0-22.0$ & $19.1 \pm 0.6$ & $95.5 \pm 3.1$ & 74.9 & $55.0-85.0$ & $72.9 \pm 3.4$ & $97.3 \pm 4.5$ \\
\hline
\end{tabular}

anformation value only

${ }^{b}$ No reference value available 
[26]. Under best conditions ${ }^{133} \mathrm{Ba}$ may be an ideal tracer, but even when measuring ${ }^{226} \mathrm{Ra}$ in ${ }^{226} \mathrm{Ra}$ spiked mineral water a somewhat different behavior between radium and barium during the separation steps was observed. As presented in Table 4, chemical yields for ${ }^{133} \mathrm{Ba}$ are in general higher than those measured for ${ }^{226} \mathrm{Ra}$. The same effect we saw also in soil samples spiked with ${ }^{133} \mathrm{Ba}$ and with ${ }^{225} \mathrm{Ra}$.

One problem that has not been solved yet is, that plutonium and neptunium isotopes will interfere the alpha spectrometry measurements if present in the sample. Under the described conditions (see chapter 2) U/TEVA - Spec resin does not quantitatively separate plutonium and neptunium from uranium and thorium [24]. Further investigations on this topic is needed, also in order to test this method with regard to its use as a monitoring system in case of accidental liberation of alpha emitting radionuclides to the environment.

\section{Conclusions}

Alpha liquid-scintillation spectrometry in combination with U/TEVA - Spec resin is an effective method for analyzing uranium thorium and radium in low-level environmental samples. U/Th-disequilibria in soil can easily and accurately be measured without using any uranium or thorium tracers. This method may probably also be used as a low-level monitoring system with accurate and fast analysis of different alpha-emitters.

\section{Acknowledgements}

We highly appreciate suggestions from Dr. H. Surbeck and Dr. M. Burger. This work was supported by the Swiss National Science Foundation and the AC-Laboratorium Spiez.

\section{References}

1. Von Gunten, H. R., Surbeck, H., Rössler, E.: Uranium Series Disequilibrium and High Thorium and Radium Enrichments in Karst Formations. Environ. Sci. Technol. 30, 1268 (1996).

2. Horrocks, D. L., Studier, M. H.: Low-level Plutonium-241 Analysis by Liquid Scintillation Techniques. Anal. Chem. 30, 1747 (1958).

3. Horrocks, D. L.: Alpha particle energy resolution in liquid scintillators. Rev. Sci. Instrum. 35 (3), 334 (1964).

4. Keough, R. F., Powers, G. J.: Determination of plutonium in biological materials by extraction and liquid scintillation counting. Anal. Chem. 42, 419 (1970).

5. McDowell, W. J.: Liquid scintillation Counting Techniques for the Higher Actinides. In: Organic Scintillators and Liquid Scintillation Counting (D. L. Horrocks and C. T. Peng, eds.). Academic Press, New York 1971.

6. Horrocks, D. L.: Measurements of low level of normal uranium in water and in urine by liquid scintillation alpha counting. Nucl. Instrum. Methods 117, 589 (1974).

7. McDowell, W. J., Coleman, C. F.: Combined Solvent Extraction - Liquid Scintillation methods for Radioassay of Alpha Emitters. In: Proceedings International Solvent Extraction Conference 1974. Society of Chemical Industry, London 1974.
8. Ham, G. J., Stradling, G. N., Breadmore, S. E.: Determination of americium and curium in biological samples by extraction and liquid scintillation counting. Anal. Chem. 49, 1268 (1977).

9. Thorngate, J. H., McDowell, W. J., Christian, D. J.: An Application of Pulse Shape Discrimination to Liquid Scintillation in Alpha Spectrometry. Health Phys. 27, 123 (1974).

10. McDowell, W. J., McDowell, B. L.: Liquid scintillation alpha spectrometry, CRC Press, Inc., Boca Raton 1994, p. 97.

11. Thorngate, J. H., Christian, D. J.: Optimization of the Detector and Associated Electronics used for High-Resolution Liquid-Scintillation Alpha Spectrometry. Health Phys. 33, 443 (1977).

12. Case, G. N., McDowell, W. J.: An improved Sensitive Assay for Polonium-210 by Use of a Background-Rejecting Extractive Liquid-Scintillation Method. Talanta 29, 845 (1982).

13. Cadieux, J. R.: Evaluation of a photon/electron-rejecting alpha liquid scintillation (PERALS) spectrometer for the measurements of alpha-emitting radionuclides. Nucl. Instrum. Meth. Phys. Res. A299, 119 (1990).

14. McDowell, W. J., McDowell, B. L.: Liquid scintillation alpha spectrometry, CRC Press, Inc., Boca Raton 1994, p. 129.

15. Möbius, S., Kamolchote, P., Roeksbutr, W.: Use of extractive scintillation and pulse shape analysis for environmental alpha-assay. Sci. Total Environ. 130/131, 467 (1993).

16. McDowell, J. W., Farrer, D. T., Billings, M. R.: Plutonium and Uranium Determination in Environmental Samples: Combined Solvent Extraction - Liquid Scintillation Method. Talanta 21, 1231 (1974)

17. Bouwer, E. J., McKlveen, J. W., McDowell, W. J.: A solvent extraction liquid scintillation method for assay of uranium and thorium in phosphate-containing materials. Nucl. Technol. 42, 102 (1979)

18. Metzger, R., McKlveen, J. W., Jenkins, R., McDowell, J. W.: Specific activity of uranium and thorium in marketable rock phosphate as a function of particle size. Health Phys. 39, 69 (1980).

19. Surbeck, H.: Determination of natural radionuclides in drinking water; a tentative protocol. Sci. Total Environ. 173/ 174, 91 (1995)

20. McDowell, W. J., McDowell, B. L.: Liquid scintillation alpha spectrometry, CRC Press, Inc., Boca Raton 1994, p. 142.

21. Friedlander, G., Kennedy, J. W., Macias, E. S., Miller, J. M.: Nuclear and Radiochemistry, 3rd ed., John Wiley and Sons, Inc., New York 1981, p. 256.

22. McDowell, W. J., McDowell, B. L.: Liquid scintillation alpha spectrometry, CRC Press, Inc., Boca Raton 1994, p. 122.

23. McDowell, W. J., McDowell, B. L.: Liquid scintillation alpha spectrometry, CRC Press, Inc., Boca Raton 1994, p. 25

24. Horwitz, E. P., Dietz, M. L., Chiarizia, R., Diamond, H.: Separation and preconcentration of uranium from acidic media by extraction chromatography. Anal. Chim. Acta 266, 25 (1992).

25. McDowell, W. J., McDowell, B. L.: Liquid scintillation alpha spectrometry, CRC Press, Inc., Boca Raton 1994, p. 137.

26. Case, G. N., McDowell, W. J.: Separation of Radium and Its Determination by Photon/Electron-Rejecting Alpha Liquid Scintillation Spectrometry. In: Proceedings of the 33rd Annual Conference on Bioassay, Analytical and Envionmental Radiochemistry, 6-8 Oct. 1987, Berkeley, 1987.

27. McDowell, J. W., Amdsten, B. A., Case, G. N.: The Synergistic Solvent Extraction of Radium from Alkaline Media by Dicyclohexano-21-Crown-7 Combined with 2-Methy12-Heptyl Nonanoic Acid: Equilibrium Reactions and Metal Ion Competition. Sol. Extr. Ion Exch. 7, 377 (1989). 
